\title{
PDCD4 wt Allele
}

National Cancer Institute

\section{Source}

National Cancer Institute. PDCD4 wt Allele. NCI Thesaurus. Code C94699.

Human PDCD4 wild-type allele is located in the vicinity of 10q24 and is approximately 28 $\mathrm{kb}$ in length. This allele, which encodes programmed cell death protein 4, may play a role in the modulation of both translation and apoptosis. The gene may act as a tumor suppressor. 